\title{
Coupled use of sediment phosphorus speciation and pigment composition to infer phytoplankton phenology over 700 years in a deep oligotrophic lake
}

\author{
Alfred Theodore N. K. Kpodonu • David P. Hamilton • Adam Hartland • \\ Daniel C. Laughlin $\cdot$ Christopher H. Lusk
}

Received: 21 March 2016/Accepted: 9 July 2016/Published online: 19 July 2016

(C) The Author(s) 2016. This article is published with open access at Springerlink.com

\begin{abstract}
Restoration and management of lake ecosystems require an understanding of natural variability in primary productivity and the factors that drive change. To understand long-term changes in, and relationships amongst phosphorus species and phytoplankton groups, a sediment core was retrieved from Lake Okataina in the central North Island of New Zealand. The core was dated to include a period of approximately 700 years, from pre-human settlement to its current state, close to natural reference conditions. Pigments representing different planktonic groups were measured vertically through the core at $1 \mathrm{~cm}$ intervals, as well as phosphorus fractions associated with apatite and $\mathrm{CaCO}_{3}, \mathrm{Fe}$ and $\mathrm{Mn}$ (oxy) hydroxides, $\mathrm{Al}$ (oxy) hydroxides and labile phosphorus. Highly significant correlations were established amongst the algal groups and the phosphorus species. Diatoms were strongly correlated with phosphorus fractions associated with permanent burial, while cyanobacteria and green algae were correlated with potentially bioavailable phosphorus. Green algae, cyanobacteria and cryptophytes co-dominated when diatom populations were reduced, and vice versa.
\end{abstract}

Responsible Editor: Breck Bowden.

A. T. N. K. Kpodonu $(\varangle) \cdot$ D. P. Hamilton ·

A. Hartland - D. C. Laughlin - C. H. Lusk

Environmental Research Institute, University of Waikato,

Private Bag 3105, Hamilton 3240, New Zealand

e-mail: tkpodonu@gmail.com
Using multiple linear regression, phosphorus fractions could be used to hindcast historical variations in the composition of algal communities (as inferred from pigments), with the exception of alloxanthin (representative of cryptophytes). Our approach provides a technique for a relatively rapid assessment of longterm changes in the major phytoplankton groups in lakes and may be used to infer natural variability in the reference state as well as partitioning the extent of alteration of phytoplankton community composition between human and natural disturbances.

Keywords Algal pigments - Phosphorus speciation · Reference state $\cdot$ Natural variability $\cdot$ Invasive mammals $\cdot$ Phenology

\section{Introduction}

Phosphorus (P) has long been known as an important nutrient and is integral to ecosystem structure and productivity (Elser et al. 2007). It is the nutrient that most commonly limits phytoplankton growth in lake ecosystems and also influences the composition of phytoplankton communities (Carpenter et al. 1998; Schindler 2012). The relationship between total phosphorus (TP) and phytoplankton biomass measured as chlorophyll $a$ has been found to be either positively linear (Jones and Bachmann 1976) or curvilinear (Hoyer and Jones 1983) across a wide range of TP 
concentrations. This relationship is also a foundation in paleolimnology for the use of diatom-inferred $\mathrm{P}$ as a measure of historic productivity (Hall and Smol 1996; Augustinus et al. 2012). While there is a wealth of information on the relationship between phosphorus and aquatic primary productivity, much less is known about the relationship between terrestrial and aquatic $\mathrm{P}$ pools and how they influence phytoplankton dynamics in lakes. This distinction is important because managing lakes demands an understanding of within-lake and whole-catchment nutrient dynamics. Furthermore, while many studies have focused on how $\mathrm{P}$ from anthropogenic sources affects lake ecosystems (Bouwman et al. 2013), the links between natural changes in catchment $\mathrm{P}$ pools and variations in lake ecosystem productivity have received much less attention.

Phosphorus enters lake ecosystems in either particulate or dissolved forms, with most dissolved $\mathrm{P}$ directly bioavailable to algae (Carey and Rydin 2011). While the bioavailability of particulate $\mathrm{P}$ in lakes has received some attention, its implications for primary productivity are still unclear (Boström et al. 1988; Abell and Hamilton 2013). In the water column, dissolved $\mathrm{P}$ becomes incorporated into particulate material (e.g., by adsorption, biological assimilation) and together with particulate $\mathrm{P}$ from in-lake and catchment sources, settles out of the water column. This particulate $\mathrm{P}$ is in inorganic and organic forms (Psenner and Pucsko 1988; Søndergaard et al. 1996). The inorganic $\mathrm{P}$ is sorbed by various chemical species, yielding different properties and behavior (Hupfer et al. 1995; Fytianos and Kotzakioti 2005). Understanding sedimentary $\mathrm{P}$ speciation is critical to explaining the contribution of different $\mathrm{P}$ species to lake primary productivity because a fraction of the $\mathrm{P}$ can re-enter the water column. Processes that return $\mathrm{P}$ to the water column include bioturbation (Adámek and Maršálek 2013; Bajer and Sorensen 2015), resuspension (Horppila and Nurminen 2003; Burger et al. 2007) and diagenesis (Nurnberg 2009; Loh et al. 2013). However, changes in sedimentary P speciation have not previously been related to long-term dynamics of phytoplankton communities.

Several lake sediment studies have focused on the role of internal loading of $\mathrm{P}$ to the water column (Wilson et al. 2010; Homyak 2012) and the loss of P through sedimentation and burial (Kopacek et al. 2005; Norton et al. 2008). They have provided valuable information on $\mathrm{P}$ dynamics in the short to medium term under varying water column and sediment pore water conditions (Kerr et al. 2011). However, sediment composition and chemical fluxes vary over multiple time scales in response to changes in temperature, redox potential, and sedimentation rates (Burdige 2006). Sediments are also derived from terrestrial soils (Kerr et al. 2011) and therefore the proportions of the various species of $\mathrm{P}$ in lake sediments will depend on the balance of $\mathrm{P}$ from both autochthonous and allochthonous sources (Kerr et al. 2011). Because different species of phytoplankton vary in their demand for $\mathrm{P}$, the speciation of $\mathrm{P}$ could in turn impact the structure of algal communities in lakes. Photosynthetic pigments in lake sediments can be used to provide essential diagnostic information on changes in the community structure of primary producers (Lizotte and Priscu 1998; Waters et al. 2013). An array of algal pigments has been used to provide knowledge of changes in community composition (Tani et al. 2009; Romero-Viana et al. 2010; Ohtsuki et al. 2015), with insights gained from analysis of specific photosynthetic pigments (Pinckney et al. 2001; Paerl et al. 2003). Derivation of relationships between $\mathrm{P}$ species and algal pigments over long time scales may help to better define "reference conditions" for phytoplankton communities and improve predictions of changes in phytoplankton diversity.

The aim of this study was to understand long-term (ca. 700 year) changes in sediment $\mathrm{P}$ species using sequential extraction, and examine relationships to lake phytoplankton community composition derived from sediment algal pigment analysis. We chose a deep oligotrophic lake as a study site because it may be considered as a proxy for a natural reference site, with minimal anthropogenic influence. Specifically, we used a dated sediment core to determine the dominant $\mathrm{P}$ and phytoplankton species in the lake between $\mathrm{AD}$ 1314 (Kaharoa eruption) and AD 2009, and to infer some of the historical drivers of changes in phytoplankton phenology.

\section{Methods}

Study site

The study site was Lake Okataina $\left(38^{\circ} 07^{\prime} \mathrm{S}\right.$; $\left.176^{\circ} 25^{\prime} \mathrm{E}\right)$, one of the lakes in the Okataina Volcanic caldera (OVC) in the central North Island of New 
Zealand (Fig. 1). Amongst New Zealand lakes, Okataina may be considered close to a natural reference state. The lake was initially an arm of the nearby Lake Tarawera but was impounded about 7000 years ago as a result of a volcanic eruption. It is $311 \mathrm{~m}$ above mean sea level, has a surface area of $10.8 \mathrm{~km}^{2}$, a maximum depth of $80 \mathrm{~m}$ and a mean depth of $39 \mathrm{~m}$. Lake Okataina has no surface outlet but drains underground toward Lake Tarawera. The lake is fed by two small permanent streams, with stormflows and groundwater contributing most of the direct inflow to the lake (McColl 1972).

The catchment area of Lake Okataina is $62.9 \mathrm{~km}^{2}$ and is steep and prone to landslides and bank erosion (McColl 1972). Surface soils in the catchment are free-draining and mostly of recent volcanic origin, dominated by allophanic material rich in $\mathrm{Al}$ and $\mathrm{Si}$ (Parfitt 1990). Eighty-one percent of the catchment area is native forest, $10 \%$ is used for dry-stock farming, $8 \%$ is exotic pine (Pinus radiata) plantations and the remaining $1 \%$ includes roads, car parks and buildings (Scholes and Bloxham 2007). Around $19 \%$ of the catchment area, including the area of dry-stock farming, exotic forest and settlements, has at one time been logged (Stafford 1967).

Lake Okataina currently has a trophic level index (TLI) (Burns et al. 1999) of approximately 2.5, indicative of oligotrophic status. It is continuously thermally stratified about 9 months in each hydrological year and vertically mixed between the austral winter months of June and August. The chlorophyll $a$ concentration varies between 4 and $8 \mu \mathrm{g} \mathrm{L}^{-1}$ over an annual cycle, with highest levels recorded during the period of mixing in August (Jolly 1968). Although records of dissolved oxygen prior to 1980 showed the lake hypolimnion remained oxygenated throughout stratification (Jolly 1968; Fish 1970; McColl 1972), records over the past 10 years indicate anoxia of a large proportion of the hypolimnion volume (Pearson et al. 2010).

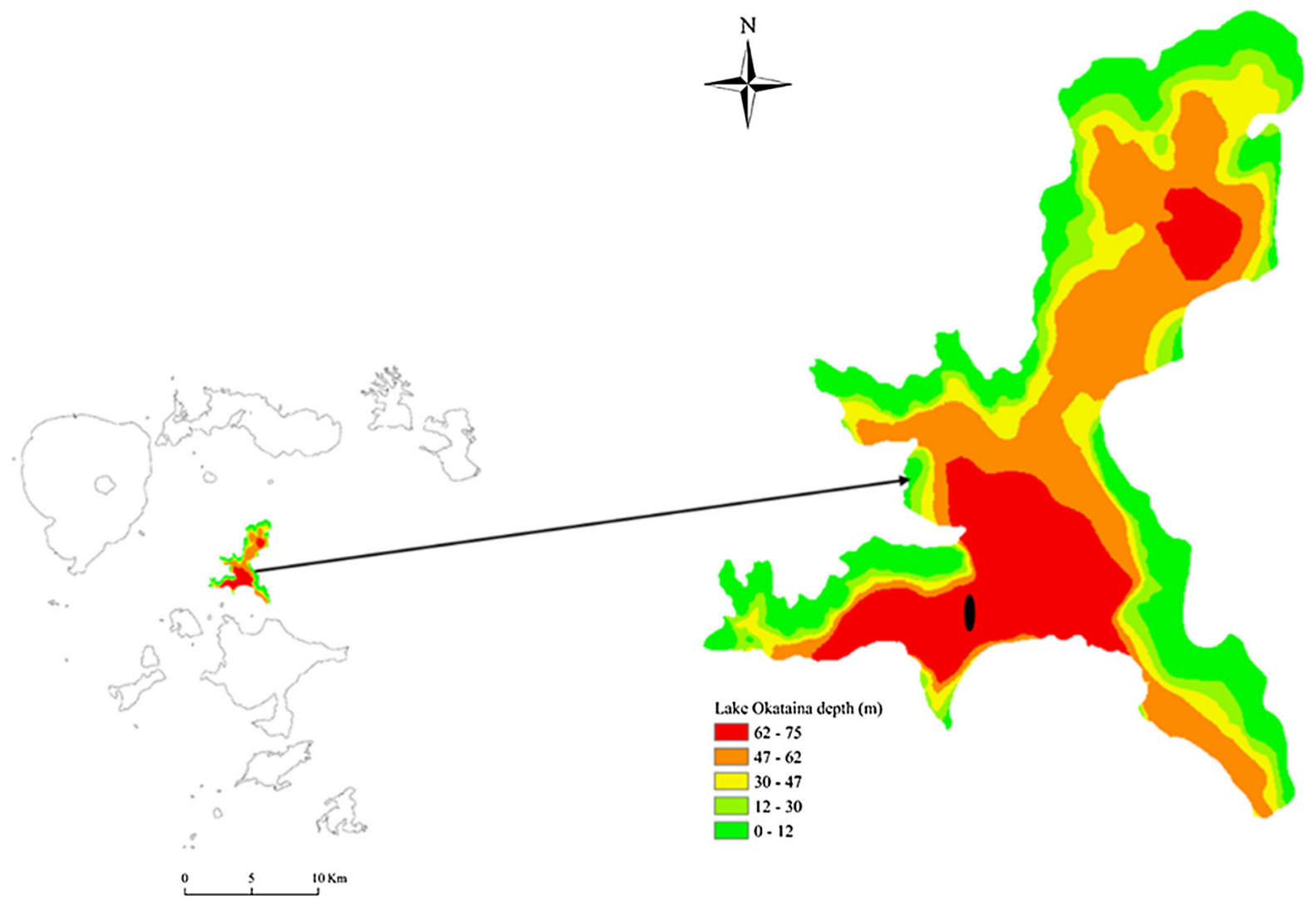

Fig. 1 Bathymetric map of Lake Okataina with depth contours mapped by colours and juxtaposed amongst other lakes of the Rotorua region. The black dot is the sampling point 
Lake Okataina catchment has been affected by disturbances of anthropogenic and natural origin during the last millennium. Polynesians are thought to have settled in and around the Okataina catchment between the late 13th and early 14th century prior to the Kaharoa eruption of AD $1314 \pm 12$ (Hogg et al. 2003). Early Polynesian settlers used fire to clear forest while some logging took place in the late 19th century mainly for the production of Māori canoes (Stafford 1967). On 10 June 1886, Mt Tarawera erupted and damaged large tracts of vegetation in the catchment (Clarkson and Clarkson 1983). Europeans first settled in and around the catchment in the early 20th century and introduced mammals into the forest as well as rainbow trout (Oncorhynchus mykiss) to the lake. Currently, there are known populations of the dama wallaby (Macropus eugenii), wild boar (Sus scrofa) and red deer (Cervus elaphus) in the catchment, and the Australian brushtail possum (Trichosurus vulpecula) is widespread. These populations have opened up the forest canopy, exposing soils to increased run-off (Allen et al. 1984; Bardgett et al. 1998; Wardle et al. 2001).

Core retrieval

A $48 \mathrm{~cm}$ sediment core was retrieved from Lake Okataina using a Swedish gravity corer (Pylonex HTH $70 \mathrm{~mm}$ ) with a $60 \times 600 \mathrm{~mm}$ Plexiglas core barrel. Two tephras were identified as white and grey colored layers in the sediment core. The depth at which they occurred in the cores was recorded (40 and $48 \mathrm{~cm}$ down the core barrel respectively). The core was extruded and separated into $50 \mathrm{ml}$ polypropylene centrifuge tubes at $1 \mathrm{~cm}$ vertical intervals. The extruded sediment samples were transported on ice in a dark chamber to the laboratory for subsequent analysis.

\section{Core dating}

The presence of two clearly identifiable and dated tephra layers in the sediment core was useful for crossvalidation of the dates determined from ${ }^{210} \mathrm{~Pb}$ analysis. The extracted tephra were identified based on (Hogg et al. 2003; Lowe et al. 2013). Dried sediment samples from each depth were also submitted to the Radiocarbon Unit (University of Waikato, New Zealand), for the determination of ${ }^{210} \mathrm{~Pb},{ }^{137} \mathrm{Cs}$ and ${ }^{266} \mathrm{Ra}$ activity. The ${ }^{210} \mathrm{~Pb}$ gamma-ray activity was counted under
$46.52 \mathrm{keV}$ emission for 43,200-259,200 s using a Canberra germanium well detector $(1 \times 4 \mathrm{~cm})$, (Meriden, USA) with $22.5 \%$ efficiency for ${ }^{60} \mathrm{Co}$. The unsupported ${ }^{210} \mathrm{~Pb}$ activity was estimated by subtracting the constant background ${ }^{210} \mathrm{~Pb}$ activity from the total ${ }^{210} \mathrm{~Pb}$. Ages of the samples were calculated based on the constant rate of supply model developed by Appleby and Oldfield (1978). Ages older than $\sim 150$ years were extrapolated assuming that sedimentation rate was constant. Visual evidence of tephra was confirmed from their mineralogy and major element glass chemistry, as the Tarawera and Kaharoa eruptions have previously been aged at AD 1886 and $1314 \pm 12$, respectively, using wiggle matching and radiometric techniques (Lowe et al. 2013). Mass accumulation rates of the sediment were then used to calculate the age of the sediment layers between the Kaharoa and Tarawera tephra. Considering that the Kaharoa core has a \pm 12 year uncertainty and ${ }^{210} \mathrm{~Pb}$ calibration of the modern sediments \pm 0.1 year, our earliest dating has an error of \pm 13 year.

Extraction and analyses of algal pigments and phosphorus species

Algal pigments (Table 1), proxies of past variation in the taxonomic composition of algal communities, were extracted from core sediments. The pigments were extracted on the same day the core was collected, immediately upon its arrival at the laboratory. Extraction followed methods previously described by Leavitt et al. (1989). $50 \mathrm{mg}$ of wet sediment from each depth was soaked in $6 \mathrm{ml}$ of a solvent mixture of acetone, methanol and deionized water (85:15:5) and allowed to sit for $24 \mathrm{~h}$ in the dark. The supernatants were centrifuged and syringe-filtered using a $0.22 \mu \mathrm{m}$

Table 1 Primary producer groups represented by specific algal pigments

\begin{tabular}{ll}
\hline Algal group & Pigment \\
\hline Total algal abundance & Chlorophyll $a$ \\
Chlorophytes + macrophytes & Chlorophyll $b$ \\
Diatoms & Diatoxanthin \\
Chryptophytes & Alloxanthin \\
Attached cyanobacteria & Canthaxanthin \\
Colonial cyanobacteria & Myxoxanthophyll \\
Chlorophytes & Lutein \\
\hline
\end{tabular}


membrane (Sigma-Aldrich, St Louis, USA). Pigments were separated and quantified using a Dionex Ultimate 3000 HPLC with a photo diode array detector and a Sigma-Aldrich (St Louis, USA) C18 reverse column (300A pore size, $5 \mu \mathrm{m}$ particle size, $4.6 \mathrm{~mm}$ ID $\times 250 \mathrm{~mm}$ ). The mobile phase gradients consisted of a mixture of methanol and $0.5 \mathrm{M}$ ammonium acetate $(80: 20 \mathrm{v}: \mathrm{v})$ as solvent $\mathrm{A}$ and a mixture of methanol and acetone (70:30 v:v) as solvent B. A combined gradient and isocratic elution technique was used for the analytical separation. An injection volume of $1 \mu \mathrm{l}$ was used at an initial flow rate of $0.1 \mathrm{ml} / \mathrm{min}$ and flow rate was increased from $0.1 \mathrm{ml} / \mathrm{min}$ until a final flow rate of $1.5 \mathrm{ml} / \mathrm{min}$ was attained. Pigments were identified using retention times of known authentic standards (canthaxanthin, myxoxanthophyll, alloxanthin, diatoxanthin, lutein and chlorophyll $b$ and a) (Sigma-Aldrich, St Louis, USA). Pigment concentrations were calculated by comparing spectral peaks to the peaks of standards of known concentration, and expressed as $\mu \mathrm{g} \mathrm{g}^{-1}$ wet sediment.

Phosphorus species from each layer in the core were determined by sequential extraction following a modification of the method of Psenner and Pucsko (1988). One gram aliquots of the wet sediment sample from each depth were dispensed into $50 \mathrm{ml}$ centrifuge tubes and thereafter subjected to the following sequential extraction procedure:

1. $1 \mathrm{M} \mathrm{NH}_{4} \mathrm{Cl}\left(\mathrm{pH} 7\right.$ at $25{ }^{\circ} \mathrm{C}$ ) was added and the mixture was left for $1 \mathrm{~h}$ and homogenized to obtain loosely adsorbed, exchangeable and pore water fractions of $\mathrm{P}$.

2. $0.1 \mathrm{M}$ of $\mathrm{NaHCO}_{3}$-buffered $0.1 \mathrm{M} \mathrm{Na}_{2} \mathrm{~S}_{2} \mathrm{O}_{4}$ (bicarbonate-dithionite, BD) at $40{ }^{\circ} \mathrm{C}$ was added and the mixture was left for $30 \mathrm{~min}$ to extract reducible fractions of $\mathrm{P}$ associated with (oxy) hydroxides of $\mathrm{Fe}$ and $\mathrm{Mn}$.

3. $0.1 \mathrm{M} \mathrm{NaOH}$ at $25{ }^{\circ} \mathrm{C}$ was added and the mixture was left for $16 \mathrm{~h}$ to release fractions associated with $\mathrm{Al}$ (oxy) hydroxides as well as some organic and biogenic $\mathrm{P}$.

4. $\quad 0.5 \mathrm{M} \mathrm{HCl}$ at $25{ }^{\circ} \mathrm{C}$ was added and the mixture was left for $16 \mathrm{~h}$ to dissolve fractions associated with apatite and $\mathrm{CaCO}_{3}$.

5. $1 \mathrm{M} \mathrm{NaOH}$ at $85{ }^{\circ} \mathrm{C}$ was added and the mixture was left for $24 \mathrm{~h}$ to solubilize residual material and release recalcitrant fractions.
The $50 \mathrm{ml}$ centrifuge tubes containing the sediment and the extraction solution were capped and shaken in a water bath at the required temperatures for the period specified in each step. The tubes were then centrifuged at $\sim 7000 \mathrm{rpm}$ for $20 \mathrm{~min}$, the supernatant collected and the sediment rinsed with the extraction solution, centrifuged and decanted a second time. Concentrations of $\mathrm{Al}, \mathrm{Fe}$ and fractions associated with (oxy) hydroxides of $\mathrm{Fe}$ and $\mathrm{Mn}, \mathrm{Al}$ (oxy) hydroxides, apatite and $\mathrm{CaCO}_{3}$, and refractory fractions were analyzed on a Perkin-Elmer (Massachusetts, USA) SCIEX ELAN DRC II inductively-coupled plasma mass spectrometer (ICP-MS). The labile fractions were also analyzed using ICP-MS while the fraction associated with (oxy) hydroxides of $\mathrm{Fe}$ and $\mathrm{Mn}$ was again measured using the molybdate-blue method to determine the reactive component of $\mathrm{P}$. The difference between the ICP-MS concentration and the molybdate-blue method was taken to be the nonreactive (organic P) component. Table 2 summarizes the methods and the associated fractionation steps used for $\mathrm{P}$ speciation.

\section{Flux calculation}

Concentrations of pigments and $\mathrm{P}$ species were converted to fluxes using mass accumulation rates $(M A R)$ instead of sediment accumulation rates. While sediment accumulation rate is an important tool in characterizing changes to sediment loads and compaction of sediments, its use in paleolimnology is complicated because the observed changes are a consequence of compaction and/or diagenesis (Stephens et al. 2012). The use of MAR is therefore essential to remove concentration and early diagenesis effects (Street-Perrott et al. 2007). Using the concentrations of the pigments and $\mathrm{P}$ species, we calculated $\operatorname{MAR}\left(\mathrm{kg} \mathrm{m}^{-2}\right.$ year $\left.^{-1}\right)$ as:

\section{$M A R=\rho_{d r y} \times S A R$}

where $\rho_{d r y}\left(\mathrm{~kg} \mathrm{~m}^{-3}\right)$ is the dry sediment density,

$\operatorname{SAR}\left(\mathrm{m} \mathrm{year}^{-1}\right)$ is the sediment accumulation rate calculated as:

$S A R=\frac{\Delta z}{\Delta t}$ 
Table 2 Phosphorus fractions recovered in the different sequential analytical steps and the solvents used in their recovery

\begin{tabular}{lll}
\hline Step & Solvent & P form \\
\hline 1 & $\mathrm{NH}_{4} \mathrm{Cl}$ & Labile P \\
2 & Bicarbonate-dithionite (BD) at $40{ }^{\circ} \mathrm{C}$ & Redox sensitive P (Fe-P) \\
3 & $\mathrm{NaOH}$ at $25^{\circ} \mathrm{C}$ & Al bound P (Al-P) \\
4 & $\mathrm{HCl}$ at $25^{\circ} \mathrm{C}$ & Apatite bound P (Ca-P) \\
5 & $\mathrm{NaOH} 85^{\circ} \mathrm{C}$ & Organic refractory P (Re-P) \\
6 & Molybdate blue TP-step 2 & Organic P (Org-P) \\
7 & Step $1-5$ & Total extractable P (TEP) \\
\hline
\end{tabular}

where $\Delta \mathrm{z}$ is the total length of the sediment core (m), and $\Delta \mathrm{t}$ is the total time span corresponding to the length of the sediment core (y).

The fluxes of each $\mathrm{P}$ fraction were calculated as a percentage of total extractable phosphorus (TEP). Similarly, for pigments, concentrations were calculated as a percentage of chlorophyll $a$ per year. Core stratigraphies were constructed based on the percentage change in the $\mathrm{P}$ fractions and pigments.

\section{Statistical techniques}

Pearson moment correlation was used to determine the relationship between the $\mathrm{P}$ species and phytoplankton pigments. Nonmetric multidimensional scaling (NMDS) with the vegan package (Oksanen et al. 2013) was used to project the distribution of $P$ species on the clustering of algal pigments.

To further determine whether phytoplankton groups could be defined by multiple $\mathrm{P}$ species, we employed generalized additive models (GAMs) in time series mode (Zuur et al. 2007). Smoothed functions were used in GAMs to describe both linear and non-linear relationships between the predictor variables (P species) and the response variables (algal pigments). A stepwise approach was used and the most parsimonious models were selected based on Akaike information criterion (AIC) and fed into a generalized linear model (GLM) to create predictive models. GAMs were used in preference to other parametric techniques to account for temporal autocorrelation of model residuals, a characteristic of time series data which leads to the violation of the independence criteria on which regression modelling is based. All statistical analysis was completed in $\mathrm{R}$ version 3.1.0 (R Development Core Team 2013) with GAMs done using the mgcv package (Wood 2011).

\section{Results}

Phosphorus species in the sediment core (AD1314-AD2009)

Phosphorus speciation in the sediments can be used to delineate between refractory and bioavailable forms of phosphorus. In the Okataina core, ca. $80 \%$ of $\mathrm{P}$ fractions can be considered refractory (i.e., $\mathrm{Ca}-\mathrm{P}, \mathrm{Al}-$ $\mathrm{P}$ and $\mathrm{Re}-\mathrm{P}$ ), with the remaining $20 \%$ in labile and $\mathrm{Fe}-\mathrm{P}$ fractions that are considered to be potentially bioavailable. As a mean percentage obtained through the $1 \mathrm{~cm}$ interval core profile, $\mathrm{P}$ bound to $\mathrm{Al}$ (oxy) hydroxides was most abundant (39\% TEP), while the labile component was the least abundant ( $2 \%)$.

The $\mathrm{P}$ fractions varied through the sediment core profile, however, corresponding to the dated periods of 1314 and 2009 AD (Fig. 2). Labile P constituted about $3 \%$ of the TEP at the base of core (i.e., 1314), and gradually declined to about $0.5 \%$ of TEP by 1680 . Between 1680 and 1870 , labile P increased from 0.5 to $2.8 \%$, decreased to about $1.4 \%$ between 1870 and 1900 , then increased rapidly from 1.4 to $3.8 \%$ between 1900 and 2009. Species bound to (oxy) hydroxides of iron $(\mathrm{Fe}-\mathrm{P})$ ranged between 4 and $12 \%$ of TEP between 1314 and 1800 but increased to $18 \%$ of TEP by 1820 , then decreased to $8 \%$ of TEP by 1900. This was followed by a sharp increase to about $25 \%$ by 1950 after which time the fraction remained reasonably constant until 2009 (i.e., to the top of the core). Aluminium-bound $\mathrm{P}$ was the dominant species between 1314 and 1886, but was less prominent after 1886. It ranged between 25 and $55 \%$ of TEP, but decreased drastically from around $50 \%$ in 1886 to $<10 \%$ by 2009 . The $\mathrm{Ca}-\mathrm{P}$ species oscillated strongly between $30 \%$ of TEP (1314) and $2.5 \%$ (1700) after which time levels were relatively 

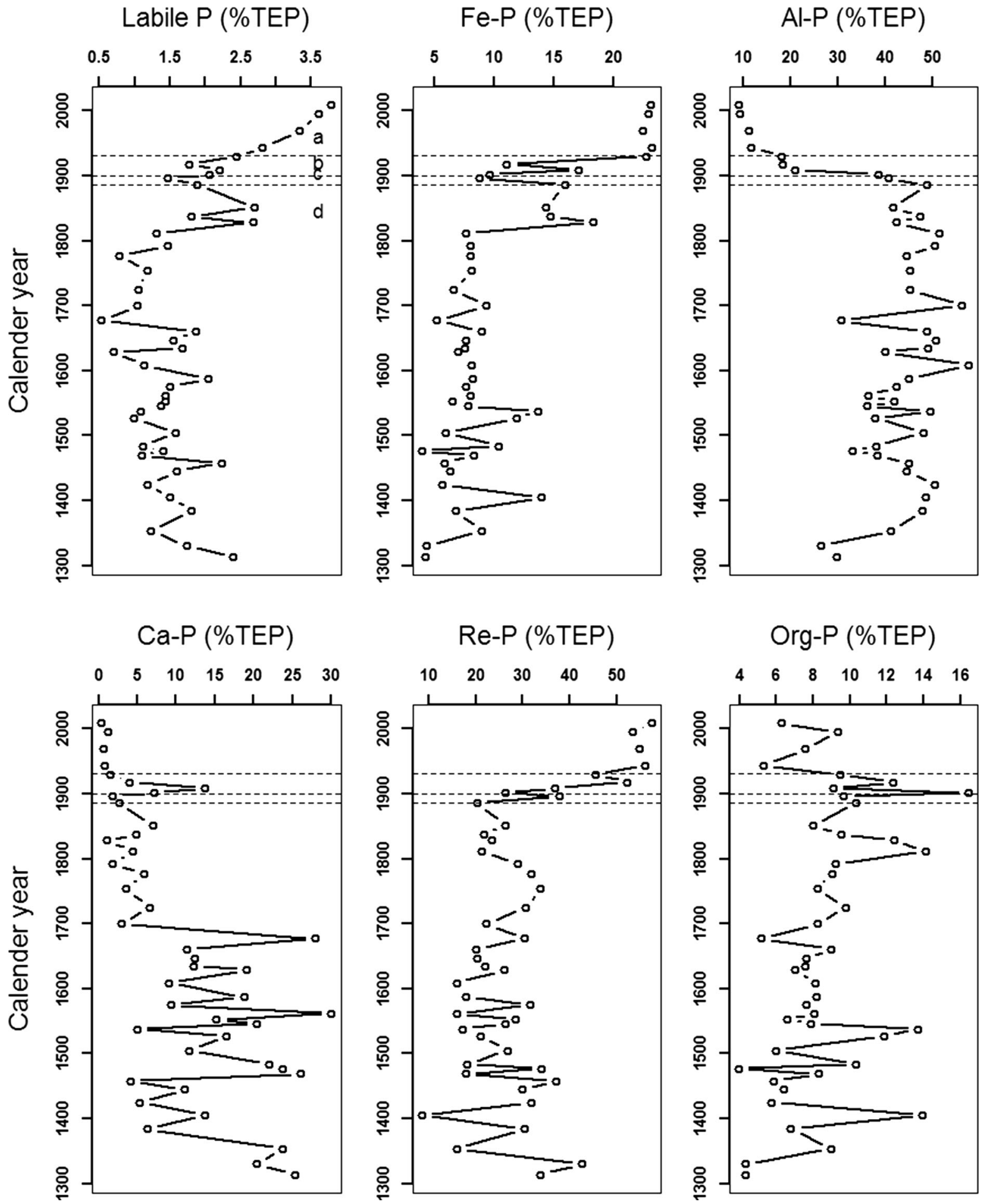

Fig. 2 Relative change of the different $\mathrm{P}$ fractions as a percentage of the total extractable P pool in the Lake Okataina core between c. 1314 and 2009. Letters represent periods associated with a increasing populations of the dama wallaby, deer and the Australian brushtail possum commencing c. 1920, b era of European settlement around c.1900, c post-Tarawera eruption of 1886, and d post-Kaharoa eruption of c. 1314 and subsequent Polynesian settlement 
stable and at the lower end of the range. However there was a sharp increase to about $15 \%$ by 1920 . Refractory organic P oscillated around $30 \%$ of TEP between 1314 and 1886 then increased rapidly after 1886 to $60 \%$ of TEP by 2009. Thus Re-P was the dominant $\mathrm{P}$ species in the most recently deposited sediments. The most stable component of the $\mathrm{P}$ species through the core was the organic fraction. It averaged about $8 \%$ of TEP through the core profile but there were spikes of up to $14 \%$ around 1400, 1550, 1800 and 1900.

Phytoplankton community dynamics in the sediment core (AD1314 - AD2009)

Changes in phytoplankton phenology of Lake Okataina were inferred from variations in pigment composition of the dated $1 \mathrm{~cm}$ slices (48) of the sediment core. Diatoxanthin, representing diatoms, was the dominant pigment, representing $59 \%$ of chlorophyll $a$ on average for the 48 core slices. It was strongly dominant between 1314 and 1810 (up to $80 \%$ of chlorophyll $a$ ), decreased to about $10 \%$ by 1810 , increased to $40 \%$ between 1900 and 1932, and decreased again to about $10 \%$ of chlorophyll $a$ by 2009 (Fig. 3).

Canthaxanthin, representing attached cyanobacteria, ranged between 0.9 and $15 \%$ of chlorophyll $a$ between 1320 and 1410 , increased sharply to about $25 \%$ by 1840 , then decreased to $15 \%$ soon after 1886 (coinciding with the Tarawera eruption). It was highest in most recently deposited sediment, at ca. $28 \%$ of chlorophyll $a$ in 2009. Myxoxanthophyll, representing colonial cyanobacteria, was relatively stable at about $0.9 \%$ of chlorophyll $a$ until 1890, then increased rapidly to about $15 \%$ by 1910 . This was followed by a sharp decrease to about $5 \%$ by 1920 before increasing again to be $10 \%$ by 2009 . Alloxanthin, representing cryptophytes, varied between 1 and $2 \%$ of chlorophyll $a$ during the entire period except between 1890 and 1932, when a major spike up to $20 \%$ was observed.

The lutein pigment is confined to chlorophytes, and can be expected to indicate chlorophyte presence similar to chlorophyll $b$ except that the latter pigment also includes macrophytes. The lutein and chlorophyll $b$ pigments showed a similar pattern through the core until about 1950. Based on lutein, chlorophytes increased gradually from about $2 \%$ of chlorophyll $a$ in 1314 to nearly $25 \%$ between 1890 and 1920 , with levels remaining elevated (12-20\%) through to 2009. Chlorophyll $b$ constituted about $15 \%$ of chlorophyll $a$ until about 1800 , increased rapidly to $70 \%$ by 1950 and remained somewhat elevated $(>35 \%)$ to 2009 .

Relationship between P species dynamics and phytoplankton phenology

NMDS was used to examine the clustering patterns of the pigments and $\mathrm{P}$ species (Fig. 4), with Pearson correlation used to examine the bivariate relationship between them. There was a negative gradient between diatoxanthin and the other algal pigments and a close clustering of lutein and canthaxanthin, while myxoxanthophyll and alloxanthin also showed some association. Chlorophyll $b$ and diatoxanthin clustered separately from other pigments and $\mathrm{P}$ species. The NMDS also showed that lutein and canthaxanthin were associated with labile $\mathrm{P}$ and $\mathrm{Re}-\mathrm{P}$ while alloxanthin and myxoxanthophyll clustered with $\mathrm{Fe}-\mathrm{P}$ and Org-P. Diatoxanthin clustered with Al-P and chlorophyll $b$ with $\mathrm{Ca}-\mathrm{P}$.

Pigments representing green algae and cyanobacteria, tended to be highly positively correlated ( $\mathrm{p}<0.001$ ), and potentially bioavailable $\mathrm{P}$ species were strongly negatively correlated with refractory species (Table 3). Relationships between P species and diatoms (diatoxanthin) were contrary to those found between $\mathrm{P}$ species and cyanobacteria, green algae and chlorophytes and macrophytes. Cryptophytes (alloxanthin) did not correlate with any $\mathrm{P}$ species apart from a weak positive correlation with organic $\mathrm{P}$ species $(\mathrm{r}=0.36, \mathrm{p}<0.05)$.

Relationships amongst algal pigments and phosphorus species

Correlations amongst the algal pigments in the sediment core are shown in Fig. 5. The pigment proxies for cyanobacteria (i.e., canthaxanthin and myxoxanthophyll) were strongly positively correlated $(p<0.01)$ with those for chlorophytes (i.e., lutein and chlorophyll $b$ ) but strongly negatively correlated with proxies for diatoms and cryptophytes.

All the phosphorus species except Org-P were correlated strongly amongst each other as shown in Fig. 6. Potentially bioavailable $\mathrm{P}$ species (i.e., labile $\mathrm{P}$ and $\mathrm{Fe}-\mathrm{P}$ ) were strongly positively correlated $(\mathrm{p}<0.01)$ but each was strongly negatively correlated $(\mathrm{p}<0.01)$ with species associated with permanent burial (Al-P and $\mathrm{Ca}-\mathrm{P}$ ). 
Canthaxanthin (\% Chl a)

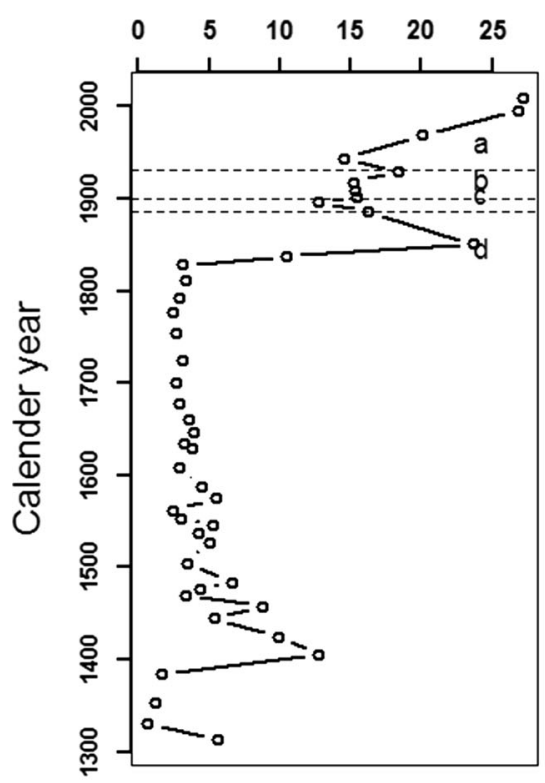

Diatoxanthin (\% Chl a)

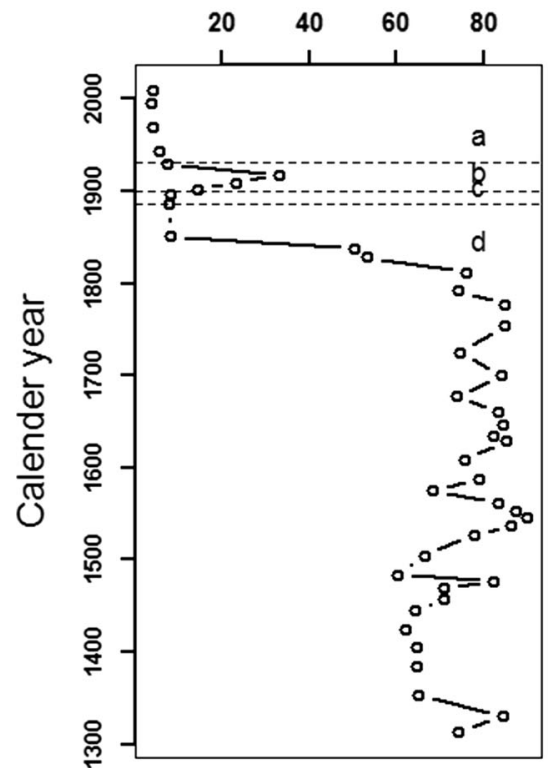

Myxoxanthophyll (\% Chl a)

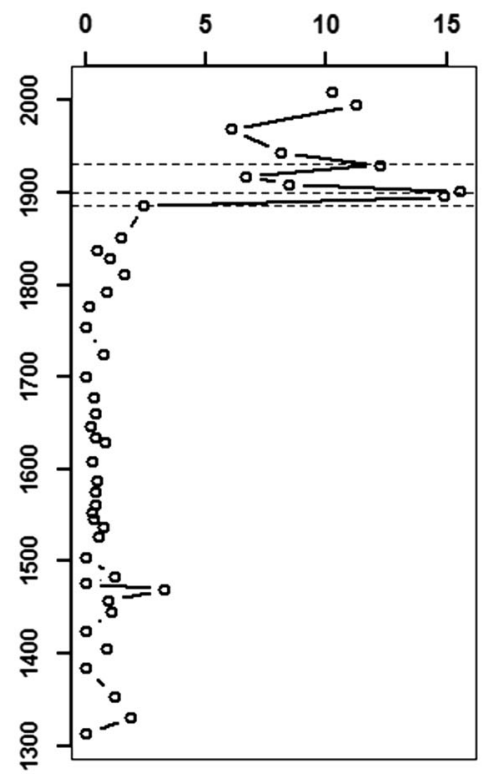

Lutein (\% Chl a)

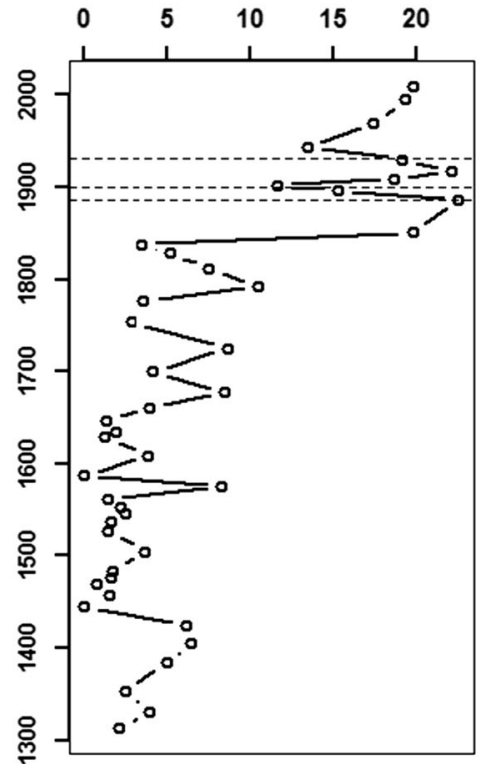

Alloxanthin (\% Chl a)

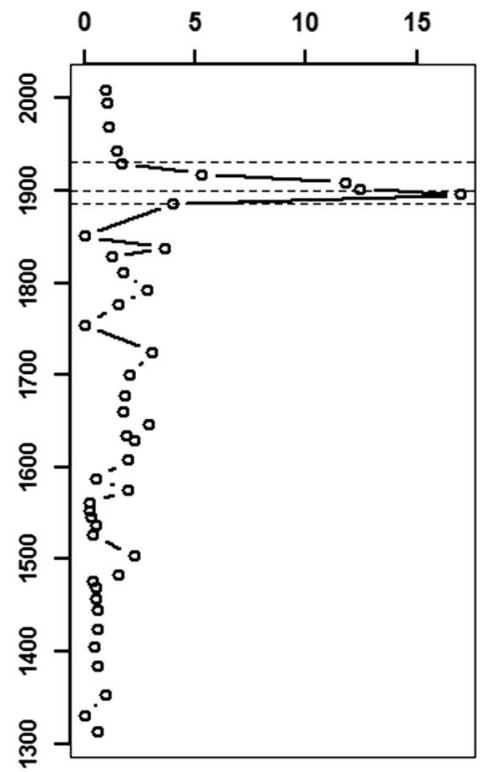

Chlorophyll b (\% Chl a)

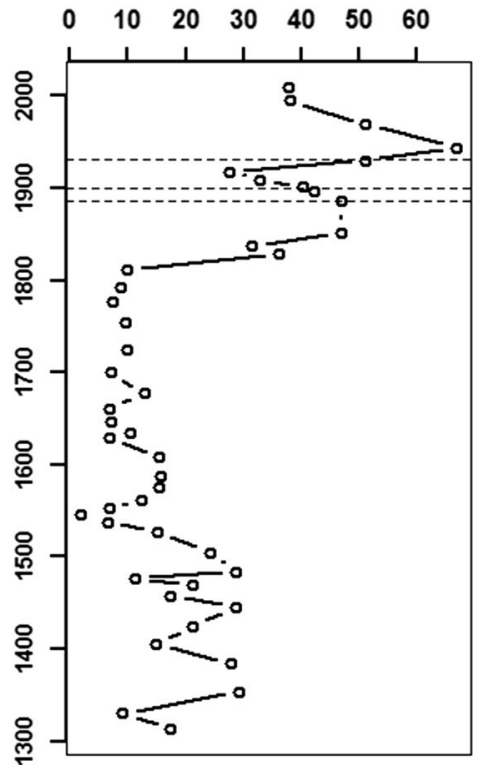

Fig. 3 Change of different algal pigments as a percentage of chlorophyll $a$ in the Lake Okataina core between c. 1314 and 2009. Letters represent periods associated with: a increasing populations of the dama wallaby, deer and the Australian

General linear model

A GLM was used to predict phytoplankton dynamics from phosphorus species. Each of the algal species brushtail possum commencing c. 1920, b era of European settlement around c. 1900, c post-Tarawera eruption of 1886 , and d post-Kaharoa eruption of c. 1314 and subsequent Polynesian settlement could be predicted to an acceptable level of significance $(\mathrm{p}<0.05)$ from various combinations of $\mathrm{P}$ species. Labile $\mathrm{P}, \mathrm{Al}-\mathrm{P}$ and $\mathrm{Ca}-\mathrm{P}$ were included as independent variables in multiple regressions that 


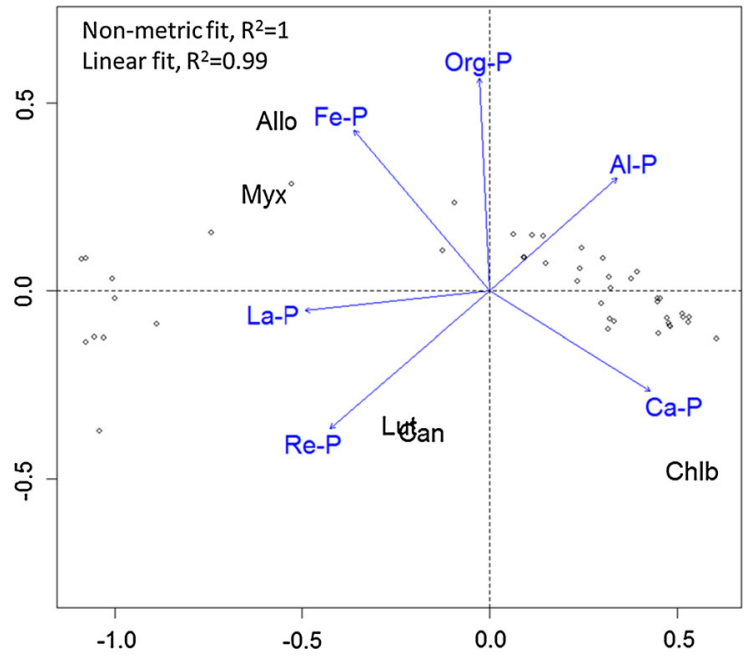

Fig. 4 NMDS of Bray-Curtis similarity matrix for alloxanthin (Allo), myxoxanthophyll (myx), lutein (Lut), canthaxanthin (Can) diatoxanthin (Dia) and chlorophyll $b$ (Chlb) as a percentage of chlorophyll $a$. Phosphorus species as a percentage of (TEP) (blue) were projected as vectors on the ordinated pigments. Open spheres represent the calendar years

explained 71, 62 and $61 \%$ of the variation in canthaxanthin, diatoxanthin and lutein, respectively (Table 4), while the relationship for $\mathrm{Fe}-\mathrm{P}$ and alloxanthin was not significant ( $p>0.05$ ). For myxoxanthophyll an additional phosphorus variable of Re-P was included in the multiple regression, while for chlorophyll $b$, only labile $\mathrm{P}$ and $\mathrm{Fe}-\mathrm{P}$ were included.

\section{Discussion}

In this study, changes in the phytoplankton phenology were reconstructed for Lake Okataina, New Zealand, in response to phosphorus speciation in lake sediments. Most phytoplankton groups delineated by pigment analysis had a strong statistical relationship to one or more of the $\mathrm{P}$ species analyzed. There was a shift from a diatom dominated community to a cyanobacteria and chlorophyte community (early 1900) which was related to a change from phosphorus species associated with permanent burial (i.e., $\mathrm{Ca}-\mathrm{P}$ and $\mathrm{Al}-\mathrm{P}$ ) to potentially bioavailable species (labile $\mathrm{P}$ and $\mathrm{Fe}-\mathrm{P})$. The focus of this discussion is on phosphorus speciation in relation to catchment disturbance and the resultant impacts on the lake phytoplankton communities inferred from sediment pigment analysis. We also discuss the application of our methodology in derivation of reference conditions for lakes in light of changes observed through the core time sequence (of ca. 700 years), including the role of changes in water levels, climate, invasive mammals and natural disasters.

The time period encompassed by our sediment core represents an era of pre-human settlement punctuated by abrupt events such as volcanic eruptions and earthquakes, which have been shown in other lakes to contribute to natural variability over time scales of 10-1000 years (Leavitt et al. 2009; Anderson 2014). Changes in $\mathrm{P}$ species in catchment soils could result from either paedogenesis (Walker and Syers 1976), anthropogenic factors (Kerr et al. 2011) or natural disasters (Fritz and Anderson 2013), ultimately affecting P loads and lake water quality. In Europe, reference conditions are benchmarked to pre 1850 when cultural eutrophication was considered to have started as a consequence of the agricultural revolution (Battarbee 2000; Bennion et al. 2011), although eutrophication in some lakes was reported prior to 1850 (Guilizzoni and Lami 2001). Variability in P species and phytoplankton pigments in our core took place long before the expansion of agriculture in New Zealand, which occurred mostly after 1870 in the North Island, with

Table 3 Pearson-moment correlation of phosphorus species (as a percentage of TEP) with algal pigment (as a percentage of chlorophyll $a$ ) based on $1 \mathrm{~cm}$ slices $(\mathrm{n}=48)$ of core retrieved from Lake Okataina

\begin{tabular}{lcccccc}
\hline & Canthaxanthin & Myxoxanthophyll & Alloxanthin & Diatoxanthin & Lutein & Chlorophyll $b$ \\
\hline Labile-P & $0.76 * * *$ & $0.53 * * *$ & 0.01 & $-0.72 * * *$ & $0.59 * * *$ & $0.67 * * *$ \\
Fe-P & $0.77 * * *$ & $0.58 * * *$ & 0.06 & $-0.77 * * *$ & $0.67 * * *$ & $0.73 * * *$ \\
Al-P & $-0.64 * * *$ & $-0.62 * * *$ & -0.06 & $0.61 * * *$ & $-0.57 * * *$ & $-0.54 * * *$ \\
Ca-P & $-0.48 * *$ & $-0.39 * *$ & -0.22 & $0.52 * * *$ & $-0.55^{* * *}$ & $-0.43 * *$ \\
Re-P & $0.59 * * *$ & $0.58 * * *$ & 0.11 & $-0.58 * * *$ & $0.61 * * *$ & $0.49 * * *$ \\
Org-P & 0.14 & 0.28 & $0.36 *$ & -0.17 & 0.2 & 0.08 \\
\hline
\end{tabular}

* $\mathrm{p}<0.05 ;{ }^{* *} \mathrm{p}<0.01 ;^{* * *} \mathrm{p}<0.001$ 

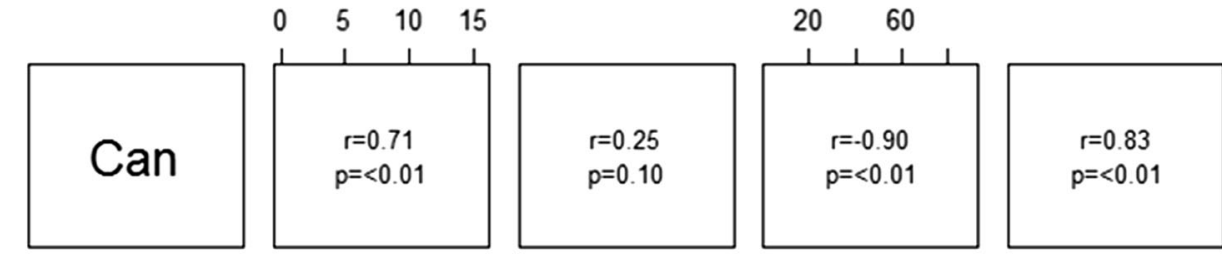

$\begin{array}{llll}0 & 20 & 40 & 60\end{array}$
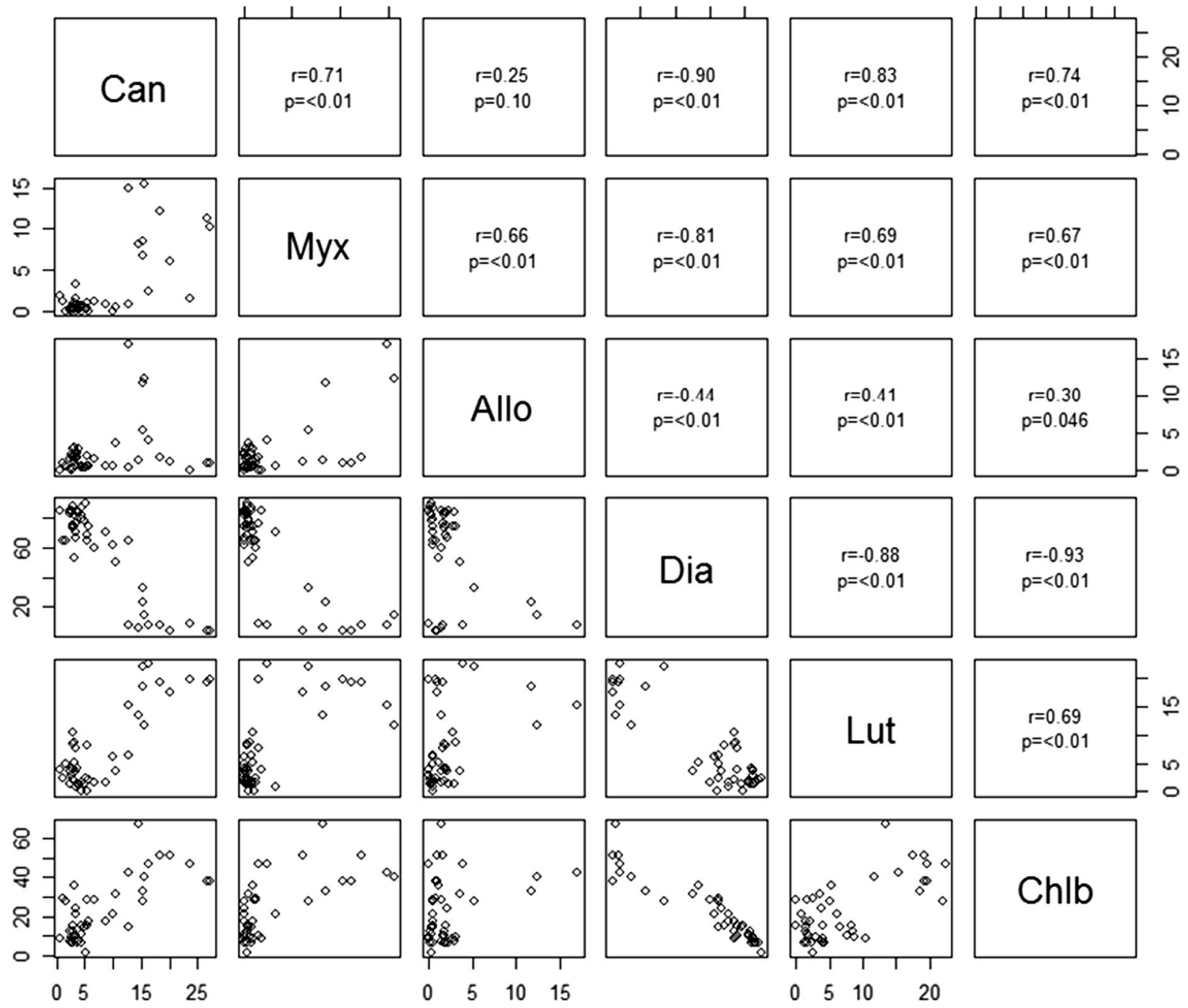

Fig. 5 Correlation matrix of the six algal pigments. Coefficients of correlation and levels of significance are given in diagonal mirror

use of chemical fertilizers reported to have started in the early 20th century (McLintock 1966). Therefore the sustained increase in the proportion of labile $\mathrm{P}$ in Lake Okataina sediments between 1800 and 1886, following negligible variation between 1314 and 1800, is not due to agricultural intensification although we cannot rule out impacts from some small amount of land clearance in the catchment for agricultural production. More recent and sustained increases in the proportion of labile $\mathrm{P}$ are of concern given the relationship to increasing proportions of cyanobacteria pigments in lake sediments. The cause of this recent increase in labile $\mathrm{P}$ is not obvious from the catchment disturbance history. Increasing numbers of free-ranging deer populations in the catchment, first introduced in the late 1800s, may, be a source of labile phosphorus as deer are known to facilitate erosion by removing forest understory and trampling soils (McDowell and Paton 2004). In-lake changes in food web trophic structure could also influence both phosphorus and pigment deposition. For example, introduction of exotic rainbow trout (O. mykiss), introduced into Lake Okataina in 1906, have been reported elsewhere to remove top herbivorous zooplankton and macroinvertebrates, resulting in a shift towards less efficient grazers and enhanced nutrient cycling which together promote higher algal productivity (Knapp et al. 2001; Parker and Schindler 2006).

The higher proportions and considerable variability of $\mathrm{Ca}-\mathrm{P}$ between $\sim 1480$ and 1700 is puzzling. A 


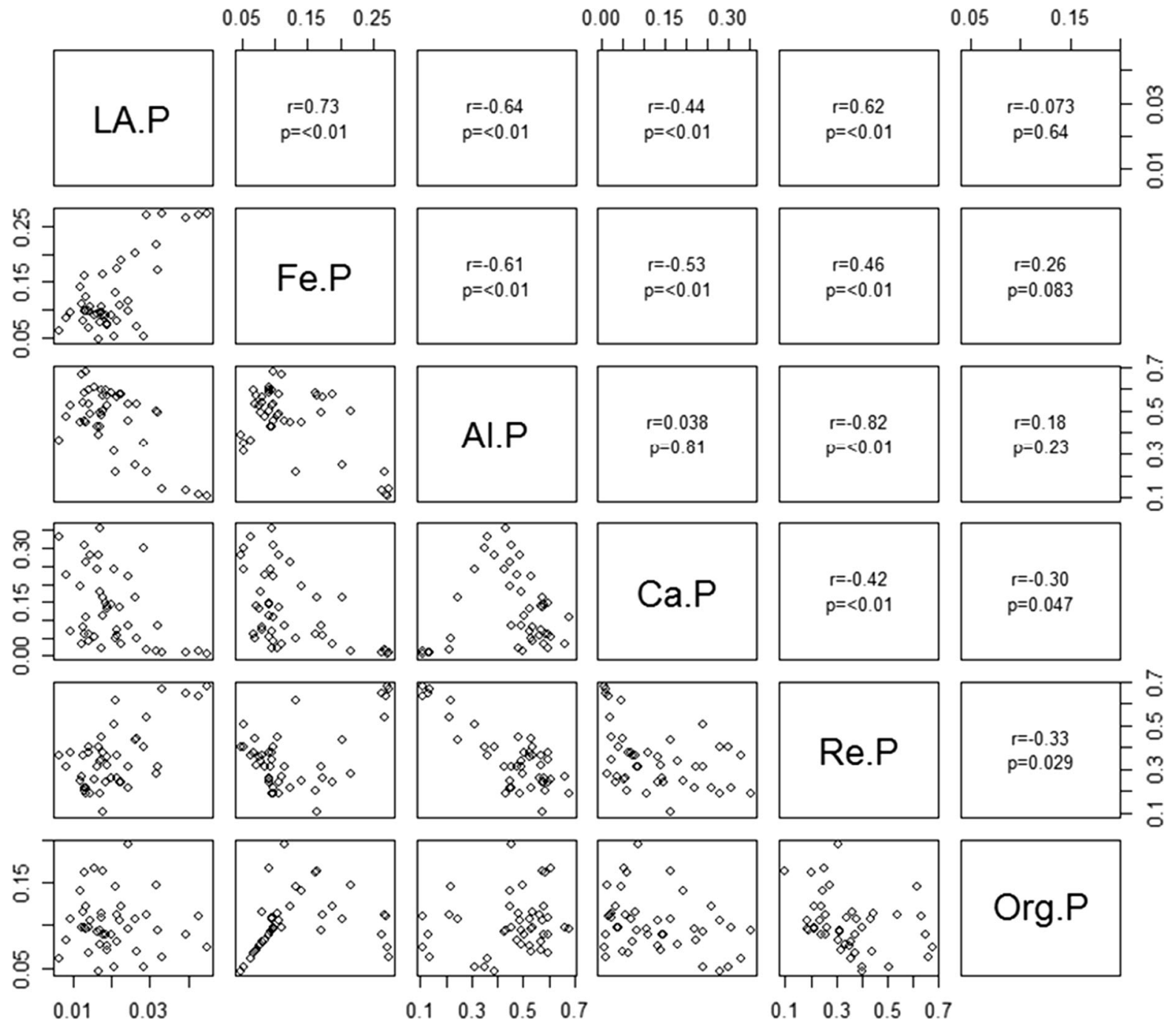

Fig. 6 Correlation matrix of the phosphorus species. Coefficients of correlation and levels of significance are given in diagonal mirror

Table 4 Multiple regression models to explain algal pigments from $\mathrm{P}$ species

\begin{tabular}{|c|c|c|c|}
\hline Response variable & Equation & $\mathrm{R}^{2}$ & $\mathrm{p}$ \\
\hline Canthaxanthin & $5.25+254.79 \mathrm{LA}-\mathrm{P}+33.57 \mathrm{Fe}-\mathrm{P}-11.30 \mathrm{Al}-\mathrm{P}-11.73 \mathrm{Ca}-\mathrm{P}$ & 0.71 & $<0.001$ \\
\hline Myxoxanthophyll & $71.53+2.64 \mathrm{LA}-\mathrm{P}-67.88 \mathrm{Fe}-\mathrm{P}-73.71 \mathrm{Al}-\mathrm{P}-65.49 \mathrm{Ca}-\mathrm{P}-52.29 \mathrm{Re}-\mathrm{P}$ & 0.62 & $<0.001$ \\
\hline Alloxanthin & $9.72-93.20 \mathrm{LA}-\mathrm{P}-7.58 \mathrm{Fe}-\mathrm{P}-6.48 \mathrm{Al}-\mathrm{P}-13.15 \mathrm{Ca}-\mathrm{P}$ & 0.10 & 0.42 \\
\hline Diatoxanthin & 58.21-684.53LA-P $-150.82 \mathrm{Fe}-\mathrm{P}+53.28 \mathrm{Al}-\mathrm{P}+70.48 \mathrm{Ca}-\mathrm{P}$ & 0.69 & $<0.001$ \\
\hline Lutein & $19.48-31.21 \mathrm{LA}-\mathrm{P}+18.27 \mathrm{Fe}-\mathrm{P}-21.72 \mathrm{Al}-\mathrm{P}-30.79 \mathrm{Ca}-\mathrm{P}$ & 0.61 & $<0.001$ \\
\hline Chlorophyll $b$ & $-3.53+529.04 \mathrm{LA}-\mathrm{P}+121.58 \mathrm{Fe}-\mathrm{P}$ & 0.58 & $<0.001$ \\
\hline
\end{tabular}

component of the variability could be associated with vegetation clearance by early Polynesian settlers who used fire as a tool for land clearance (McGlone 1989). Increases in the proportion of $\mathrm{Ca}-\mathrm{P}$ in lake sediments have been associated with land clearance (Filippelli et al. 2010) and pools of $\mathrm{Ca}-\mathrm{P}$ in catchments are generally associated with weathering of apatite-bearing rocks and are related to erosion and run-off 
(Armengol and Vidal 1988; Filippelli et al. 2010). A spike in the proportion of $\mathrm{Ca}-\mathrm{P}$ was noted following the Tarawera eruption of 1886 and $\mathrm{Ca}-\mathrm{P}$ was also very high in the bottom slices of the core, which is a period following the Kaharoa eruption of $\mathrm{AD} 1314 \pm 12$. There is evidence to suggest large-scale destruction of catchment vegetation during the 1886 Tarawera eruption (Clarkson and Clarkson 1983; McGlone 1989). Vegetation regeneration and canopy closure following the eruption took about 27 years (Timmins 1983) but the intervening period might be expected to yield higher erosion rates and therefore more $\mathrm{Ca}-\mathrm{P}$ as a fraction of TEP.

The marked increase in the Re-P component after 1886 may be attributable to the Tarawera eruption in 1886 and subsequent landslides. This pool is considered to be inert and associated with soils, terrestrial plant parts and dust entering lakes via inflows, wind and precipitation (Psenner and Pucsko 1988). The destruction of catchment vegetation during the 1886 Tarawera eruption might have introduced large amounts of Re-P-species into the lake. In 1906, 20 years after the Tarawera eruption, Re-P was about $40 \%$ of the TEP pool. Similarly, the Re-P pool represented about $40 \%$ of TEP in 1334, some 20 years after the Kaharoa eruption. Eruptions result in large additions to the sediment pool of terrestrial plant materials which are high in Re-P. The proportion of Re-P continued to increase almost for 100 years, however, following the Tarawera eruption and despite the vegetation largely recovering after 27 years (Timmins 1983). Other natural changes may be relevant to consideration of the recent sustained increase in the proportion of Re-P. For example, water levels, recorded since early 1920 s rose by $10 \mathrm{~m}$ in 1931 and $3 \mathrm{~m}$ in 1962 and 1971 (McColl 1972). While the cause of this periodic large fluctuations are not known, they are reported to have occurred after seismic activities were recorded in the catchment (Morgan 2005). These increases resulted in extensive destruction of riparian vegetation, which may have contributed additional Re-P that ultimately deposited to the lake sediments. Bank/shoreline erosion is also a common feature on the shores of the lake, a consequence of steep slopes, loose pumice soils and heavy rainfall (Cooper and Thomsen 1988). Possums, deer and wallabies, all introduced into the catchment of Lake Okataina over the past 150 years, decrease plant canopy cover, reduce the understory and in some cases cause tree dieback (Bellingham and Allan 2003). They may therefore reduce forest rainfall interception and evapotranspiration, invariably leading to increased run-off and erosion (Wardle et al. 2001), including increased Re-P loads. The impacts of vegetation clearance by invasive mammals on sediment erosion in a catchment characterized by steep slopes, heavy rainfall and wind storms (Hicks 1989) is likely to be substantial.

Burrows (1979) has indicated that annual mean air temperature from 1000 to $1900 \mathrm{AD}$ has not varied by more than $0.5{ }^{\circ} \mathrm{C}$ in the Southern Hemisphere, which suggests that climate is unlikely to have driven some of the changes observed in the core prior to $1000 \mathrm{AD}$. By contrast, Cook et al. (2002), however, reported a $1.5{ }^{\circ} \mathrm{C}$ increase in air temperature in the last 200 years, immediately followed the little ice age in New Zealand. Concomitantly there were increases in canthaxanthin, lutein and chlorophyll $b$, and reduction in diatoxanthin in Lake Okataina sediments from the past 200 years, coincided with a period in the past 200 years when air temperature has increased. In laboratory experiments, Lürling et al. (2013) and Schabhüttl et al. (2013) showed that rapid increases in temperature altered phytoplankton community composition, favoring proliferation of cyanobacteria and green algae. They postulated that diatoms, which are better adapted to cooler temperatures, may be outcompeted by cyanobacteria and chlorophytes at higher temperatures. Field experiments in a series of lakes spanning the whole of continental America have also shown a positive relationship between temperature and chlorophytes and cyanobacteria concentrations (Beaulieu et al. 2013).

The period encompassed by the core and prior to the Tarawera eruption was characterized by low to moderate variability in the proportions of phytoplankton pigments and phosphorus species, but abrupt changes associated with the eruption and then more sustained changes occurring following the eruption and through to present. Some changes may be associated with a period of warming following the Tarawera eruption but invasive mammal introductions and their proliferation appear to pose the most immediate threat to the quality of lake water as they serve as potential vectors for transferring easily erodible sediments to the lake from the catchment and could potentially facilitate landslides in this steep catchment. The effects of catchment erosion and phosphorus inputs may 
potentially be acting synergistically with impacts from trout on the trophic structure of the lake, increasing the cycling of nutrients and inducing changes in $\mathrm{P}$ species and phytoplankton pigments that are similar to low to moderate levels of nutrient enrichment. This study indicates that lakes are highly dynamic even under apparently low to moderate levels of natural perturbation, and that derivation of reference conditions should therefore reflect an inherent variability to allow better understanding of anthropogenic impacts.

Acknowledgments We thank Bay of Plenty Regional Council for funding a Ph.D. scholarship for ATNKK. We thank the Lake Okataina Management Board for allowing access to the lake and the Te Arawa Lakes Trust for granting permission for collecting sediment cores from the lake. This study was also assisted with funding provided by the Ministry of Business, Innovation and Employment (contract number: UOW X1503). We also thank Joseph Butterworth, Annie Baker and Helen Turner of the University of Waikato for assisting with the lake coring. Additionally, Steve Cameron of the ICP/MS suite at the University of Waikato helped with laser ablation techniques for the tephra geochemistry. Martin Danišík helped with the ${ }^{210} \mathrm{~Pb}$ dating.

Open Access This article is distributed under the terms of the Creative Commons Attribution 4.0 International License (http:// creativecommons.org/licenses/by/4.0/), which permits unrestricted use, distribution, and reproduction in any medium, provided you give appropriate credit to the original author(s) and the source, provide a link to the Creative Commons license, and indicate if changes were made.

\section{References}

Abell JM, Hamilton DP (2013) Bioavailability of phosphorus transported during storm flow to a eutrophic, polymictic lake. NZ J Mar Freshw Res 47:481-489

Adámek Z, Maršálek B (2013) Bioturbation of sediments by benthic macroinvertebrates and fish and its implication for pond ecosystems: a review. Aquac Int 21:1-17

Allen R, Payton I, Knowlton J (1984) Effects of ungulates on structure and species composition in the Urewera forests as shown by exclosures. NZ J Ecol 7:119-130

Anderson NJ (2014) Landscape disturbance and lake response: temporal and spatial perspectives. Freshw Rev 7:77-120

Appleby P, Oldfield F (1978) The calculation of ${ }^{210} \mathrm{~Pb}$ dates assuming a constant rate of supply of unsupported ${ }^{210} \mathrm{~Pb}$ to the sediments. Catena 5:1-18

Armengol J, Vidal A (1988) The use of different phosphorus fractions for the estimation of the trophic evolution of the Sau reservoir. Arch für Hydrobiol 30:61-70

Augustinus P, Cochran U, Kattel G, D'Costa D, Shane P (2012) Late Quaternary paleolimnology of Onepoto maar,
Auckland, New Zealand: implications for the drivers of regional paleoclimate. Quat Int 253:18-31

Bajer PG, Sorensen PW (2015) Effects of common carp on phosphorus concentrations, water clarity, and vegetation density: a whole system experiment in a thermally stratified lake. Hydrobiologia 746:303-311

Bardgett RD, Wardle DA, Yeates GW (1998) Linking aboveground and below-ground interactions: how plant responses to foliar herbivory influence soil organisms. Soil Biol Biochem 30:1867-1878

Battarbee RW (2000) Paleolimnological approaches to climate change, with special regard to the biological record. Quat Sci Rev 19:1-5

Beaulieu M, Pick F, Gregory-Eaves I (2013) Nutrients and water temperature are significant predictors of cyanobacterial biomass in a 1147 lakes data set. Limnol Oceanogr 58:1736-1746

Bellingham P, Allan C (2003) Forest regeneration and the influences of white-tailed deer (Odocoileus virginianus) in cool temperate New Zealand rain forests. For Ecol Manag 175:71-86

Bennion H, Battarbee RW, Sayer CD, Simpson GL, Davidson TA (2011) Defining reference conditions and restoration targets for lake ecosystems using palaeolimnology: a synthesis. J Paleolimnol 45:533-544

Boström B, Persson G, Broberg B (1988) Bioavailability of different phosphorus forms in freshwater systems. Hydrobiologia 170:133-155

Bouwman AF, Bierkens MFP, Griffioen J, Hefting MM, Middelburg JJ, Middelkoop H, Slomp CP (2013) Nutrient dynamics, transfer and retention along the aquatic continuum from land to ocean: towards integration of ecological and biogeochemical models. Biogeosciences 10:1-23

Burdige DJ (2006) Geochemistry of marine sediments. Princeton University Press, Princeton

Burger DF, Hamilton DP, Pilditch CA, Gibbs MM (2007) Benthic nutrient fluxes in a eutrophic, polymictic lake. Hydrobiologia 584:13-25

Burns NM, Rutherford JC, Clayton JS (1999) A monitoring and classification system for New Zealand lakes and reservoirs. Lake Reserv Manag 15:255-271

Burrows C (1979) A chronology for cool-climate episodes in the Southern Hemisphere 12 000-1000 year BP. Palaeogeogr Palaeoclimatol Palaeoecol 27:287-347

Carey CC, Rydin E (2011) Lake trophic status can be determined by the depth distribution of sediment phosphorus. Limnol Oceanogr 56:2051-2063

Carpenter SR, Caraco NF, Correll DL, Howarth RW, Sharpley AN, Smith VH (1998) Nonpoint pollution of surface waters with phosphorus and nitrogen. Ecol Appl 8:559-568

Clarkson BR, Clarkson BD (1983) Mt. Tarawera. 2: rates of change in the vegetation and flora of the high domes. NZ J Ecol 6:107-119

Cook ER, Palmer JG, D’Arrigo RD (2002) Evidence for a 'Medieval Warm Period'in a 1,100 year tree-ring reconstruction of past austral summer temperatures in New Zealand. Geophys Res Lett 29:14

Cooper AB, Thomsen CE (1988) Nitrogen and phosphorus in streamwaters from adjacent pasture, pine, and native forest catchments. NZ J Mar Freshw Res 22:279-291 
Elser JJ, Bracken ME, Cleland EE, Gruner DS, Harpole WS, Hillebrand H, Ngai JT, Seabloom EW, Shurin JB, Smith JE (2007) Global analysis of nitrogen and phosphorus limitation of primary producers in freshwater, marine and terrestrial ecosystems. Ecol Lett 10:1135-1142

Filippelli GM, Souch C, Horn SP, Newkirk D (2010) The preColombian footprint on terrestrial nutrient cycling in Costa Rica: insights from phosphorus in a lake sediment record. J Paleolimnol 43:843-856

Fish GR (1970) A limnological study of four lakes near Rotorua. NZ J Mar Freshw Res 4:165-194

Fritz SC, Anderson N (2013) The relative influences of climate and catchment processes on Holocene lake development in glaciated regions. J Paleolimnol 49:349-362

Fytianos K, Kotzakioti A (2005) Sequential fractionation of phosphorus in lake sediments of Northern Greece. Environ Monit Assess 100:191-200

Guilizzoni P, Lami A (2001) Paleolimnology: use of algal pigments as indicators. Encycl Environ Microbiol 3:120-133

Hall RI, Smol JP (1996) Paleolimnological assessment of longterm water-quality changes in south-central Ontario lakes affected by cottage development and acidification. Can J Fish Aquat Sci 53:1-17

Hicks BB (1989) Overview of deposition processes. In: Malanchuk JL, Nilsson J (eds) The role of nitrogen in the acidification of soils and surface waters, vol 10. Nordic Council of Ministers, Miljorapport, pp 31-321

Hogg AG, Higham TF, Lowe DJ, Palmer JG, Reimer PJ, Newnham RM (2003) A wiggle-match date for Polynesian settlement of New Zealand. Antiquity 77:116-125

Homyak PM (2012) Nitrogen and phosphorus biogeochemistry of watersheds along the western slope of the Sierra Nevada. University of California, Riverside

Horppila J, Nurminen L (2003) Effects of submerged macrophytes on sediment resuspension and internal phosphorus loading in Lake Hiidenvesi (southern Finland). Water Res 37:4468-4474

Hoyer MV, Jones JR (1983) Factors affecting the relation between phosphorus and chlorophyll a in midwestern reservoirs. Can J Fish Aquat Sci 40:192-199

Hupfer M, Gächter R, Giovanoli R (1995) Transformation of phosphorus species in settling seston and during early sediment diagenesis. Aquat Sci 57:305-324

Jolly VH (1968) The comparative limnology of some New Zealand lakes: 1. Physical and chemical. NZ J Mar Freshw Res 2:214-259

Jones JR, Bachmann RW (1976) Prediction of phosphorus and chlorophyll levels in lakes. J Water Pollut Control Fed 48:2176-2182

Kerr JG, Burford MA, Olley JM, Bunn SE, Udy J (2011) Examining the link between terrestrial and aquatic phosphorus speciation in a subtropical catchment: the role of selective erosion and transport of fine sediments during storm events. Water Res 45:3331-3340

Knapp RA, Matthews KR, Sarnelle O (2001) Resistance and resilience of alpine lake fauna to fish introductions. Ecol Monogr 71:401-421

Kopacek J, Borovec J, Hejzlar J, Ulrich K-U, Norton SA, Amirbahman A (2005) Aluminum control of phosphorus sorption by lake sediments. Environ Sci Technol 39:8784-8789

Leavitt PR, Carpenter SR, Kitchell JF (1989) Whole-lake experiments: the annual record of fossil pigments and zooplankton. Limnol Oceanogr 34:700-717

Leavitt PR, Fritz SC, Anderson N, Baker P, Blenckner T, Bunting L, Catalan J, Conley DJ, Hobbs W, Jeppesen E (2009) Paleolimnological evidence of the effects on lakes of energy and mass transfer from climate and humans. Limnol Oceanogr 54:2330-2348

Lizotte MP, Priscu JC (1998) Pigment analysis of the distribution, succession, and fate of phytoplankton in the McMurdo Dry Valley lakes of Antarctica. Wiley, New York

Loh PS, Molot LA, Nurnberg GK, Watson SB, Ginn B (2013) Evaluating relationships between sediment chemistry and anoxic phosphorus and iron release across three different water bodies. Inland Waters 3:105-118

Lowe DJ, Blaauw M, Hogg AG, Newnham RM (2013) Ages of 24 widespread tephras erupted since 30,000 years ago in New Zealand, with re-evaluation of the timing and palaeoclimatic implications of the Lateglacial cool episode recorded at Kaipo bog. Quat Sci Rev 74:170-194

Lürling M, Eshetu F, Faassen EJ, Kosten S, Huszar VL (2013) Comparison of cyanobacterial and green algal growth rates at different temperatures. Freshw Biol 58:552-559

McColl R (1972) Chemistry and trophic status of seven New Zealand lakes. NZ J Mar Freshw Res 6:399-447

McDowell R, Paton R (2004) Water and soil quality in an Otago deer farm. In: Proceedings of the New Zealand grassland association, Ashburton, pp 187-193

McGlone M (1989) The Polynesian settlement of New Zealand in relation to environmental and biotic changes. NZ J Ecol 12:115-129

McLintock AH (1966) Encyclopaedia of New Zealand. Reed, Auckland

Morgan TKKB (2005) Te Arawa, Ngati Pikiao, Ngati Kahungunu, Kai Tahu "An indigenous perspective on water recycling. Civil and Environmental Engineering," The University of Auckland, Auckland

Norton SA, Coolidge K, Amirbahman A, Bouchard R, Kopáček J, Reinhardt R (2008) Speciation of Al, Fe, and P in recent sediment from three lakes in Maine, USA. Sci Total Environ 404:276-283

Nurnberg GK (2009) Assessing internal phosphorus loadproblems to be solved. Lake Reserv Manag 25:419-432

Ohtsuki H, Awano T, Tsugeki NK, Ishida S, Oda H, Makino W, Urabe J (2015) Historical changes in the ecosystem condition of a small mountain lake over the past 60 years as revealed by plankton remains and daphnia ephippial carapaces stored in lake sediments. PLoS One 10:e0119767

Oksanen J, Blanchet FG, Kindt R, Legendre P, Minchin PR, O'Hara R, Simpson GL, Solymos P, Stevens MHH, Wagner H (2013) Package 'vegan'. Community ecology package, version 2

Paerl HW, Valdes LM, Pinckney JL, Piehler MF, Dyble J, Moisander PH (2003) Phytoplankton photopigments as indicators of estuarine and coastal eutrophication. Bioscience 53:953-964 
Parfitt RL (1990) Allophane in New Zealand-a review. Aust J Soil Res 28:343-360

Parker BR, Schindler DW (2006) Cascading trophic interactions in an oligotrophic species-poor alpine lake. Ecosystems 9:157-166

Pearson LK, Hendy CH, Hamilton DP, Pickett RC (2010) Natural and anthropogenic lead in sediments of the Rotorua lakes, New Zealand. Earth Planet Sci Lett 297:536-544

Pinckney JL, Richardson TL, Millie DF, Paerl HW (2001) Application of photopigment biomarkers for quantifying microalgal community composition and in situ growth rates. Org Geochem 32:585-595

Psenner R, Pucsko R (1988) Phosphorus fractionation: advantages and limits of the method for the study of sediment $P$ origins and interactions. Arch für Hydrobiol Beih Ergeb der Limnol 30:43-59

Romero-Viana L, Keely BJ, Camacho A, Vicente E, Miracle MR (2010) Primary production in Lake La Cruz (Spain) over the last four centuries: reconstruction based on sedimentary signal of photosynthetic pigments. J Paleolimnol 43:771-786

Schabhüttl S, Hingsamer P, Weigelhofer G, Hein T, Weigert A, Striebel M (2013) Temperature and species richness effects in phytoplankton communities. Oecologia 171:527-536

Schindler DW (2012) The dilemma of controlling cultural eutrophication of lakes. Proc R Soc B 279:4322-4333

Scholes P, Bloxham M (2007) Rotorua lakes water quality 2006 report. Environment Bay of Plenty, Whakatane, New Zealand ISSN: 11759372

Søndergaard M, Windolf J, Jeppesen E (1996) Phosphorus fractions and profiles in the sediment of shallow Danish lakes as related to phosphorus load, sediment composition and lake chemistry. Water Res 30:992-1002

Stafford DM (1967) Te Arawa: a history of the Arawa people. Reed, Auckland

Stephens T, Atkin D, Cochran U, Augustinus P, Reid M, Lorrey A, Shane P, Street-Perrott A (2012) A diatom-inferred record of reduced effective precipitation during the Last Glacial Coldest Phase (28.8-18.0 cal kyr BP) and increasing Holocene seasonality at Lake Pupuke, Auckland, New Zealand. J Paleolimnol 48:801-817

Street-Perrott F, Barker PA, Swain DL, Ficken KJ, Wooller MJ, Olago DO, Huang Y (2007) Late Quaternary changes in ecosystems and carbon cycling on Mt. Kenya, East Africa: a landscape-ecological perspective based on multi-proxy lake-sediment influxes. Quat Sci Rev 26:1838-1860

Tani Y, Matsumoto GI, Soma M, Soma Y, Hashimoto S, Kawai T (2009) Photosynthetic pigments in sediment core HDP04 from Lake Hovsgol, Mongolia, and their implication for changes in algal productivity and lake environment for the last 1Ma. Quat Int 205:74-83

Timmins SM (1983) Mt. Tarawera: 1. Vegetation types and successional trends. NZ J Ecol 6:99-105

Walker T, Syers JK (1976) The fate of phosphorus during pedogenesis. Geoderma 15:1-19

Wardle DA, Barker GM, Yeates GW, Bonner KI, Ghani A (2001) Introduced browsing mammals in New Zealand natural forests: aboveground and belowground consequences. Ecol Monogr 71:587-614

Waters MN, Smoak JM, Saunders CJ (2013) Historic primary producer communities linked to water quality and hydrologic changes in the northern Everglades. J Paleolimnol 49:67-81

Wilson TA, Amirbahman A, Norton SA, Voytek MA (2010) A record of phosphorus dynamics in oligotrophic lake sediment. J Paleolimnol 44:279-294

Wood SN (2011) Fast stable restricted maximum likelihood and marginal likelihood estimation of semiparametric generalized linear models. J R Stat Soc 73:3-36

Zuur A, Ieno E, Smith G, Reed J, Elphick C, Zuur A, Ieno E, Smith G (2007) Time series analysis of Hawaiian waterbirds. Analysing ecological data. Springer, New York 